\title{
Development of Wet Noodles Based on Cassava Flour
}

\author{
Akhmad Z. Abidin, Cinantya Devi \& Adeline \\ Department of Chemical Engineering, Faculty of Industrial Technology \\ Institut Teknologi Bandung, Jalan Ganesa No. 10 Bandung 40132, Indonesia \\ Email: zainal@che.itb.ac.id
}

\begin{abstract}
Cassava is one of Indonesia's original commodities and contains good nutrition and has high productivity and a relatively low price. Cassava flour has a high potential as a substitute for imported wheat flour that is widely used in noodle production. The main purpose of this research was to develop wet noodles from cassava flour that can compete with wet noodles from wheat flour. The research consisted of experiments with several variations of composition and production method for producing cassava flour-based wet noodles. The best result was then examined for its nutritional value, economical value, and market response, and also a comparison was made between the prepared wet noodles and the standard noodles made from wheat flour. The analysis was based on five characteristics: taste, texture, chewiness, aroma, and appearance. Relations between these characteristics with composition, materials used, and methods applied are discussed. The developed cassava flour-based wet noodle meets physical, nutritional, and economical standards. Raw materials of the noodle were cassava flour and a wheat flour composite with a 5:1 ratio, egg, gluten, soda-ash, water, and vegetable oil, while the process was completed in multiple stages. Market response showed that the cassava flour-based wet noodles were $80 \%$ similar to wheat-flour noodles.
\end{abstract}

Keywords: cassava flour; nutrition; organoleptic; wet noodles; wheat flour substitution.

\section{$1 \quad$ Introduction}

Indonesia is one of the largest wheat flour importers in the world. The average growth of wheat flour import from 2008 to 2011 is $5.1 \%$ and the wheat import reached 6.8M ton in 2011 [1]. More Indonesian foods based on wheat flour are available now than before, both in variety and number. To reduce this dependency, the Indonesian local food industry must consider local materials to substitute wheat flour as a raw material for commercial food products.

Noodles are one of the most popular Indonesian foods and the most wheatconsuming products. In West Java province for example, from BPS data [2], more than 200 tons of wet noodles are being sold every day. Table 1 shows the increase of instant noodle production in Indonesia from 2004 to 2010.

Received January $20^{\text {th }}, 2011$, Revised February $22^{\text {nd }}, 2012$, Accepted for publication February $9^{\text {th }}, 2013$. Copyright @ 2013 Published by ITB Journal Publisher, ISSN: 2337-5779, DOI: 10.5614/j.eng.technol.sci.2013.45.1.7 
Table 1 Indonesia's instant noodle production [3].

\begin{tabular}{ccc}
\hline Year & Production (tons) & Increase (\%) \\
\hline 2004 & 974.000 & $2.7 \%$ \\
2005 & 1.000 .000 & $30.0 \%$ \\
2006 & 1.300 .000 & $7.7 \%$ \\
2007 & 1.400 .000 & $6.7 \%$ \\
2008 & 1.500 .000 & $7.7 \%$ \\
2009 & 1.800 .000 & $20.0 \%$ \\
2010 & 2.000 .000 & $11.0 \%$ \\
\hline
\end{tabular}

In [4], we have proposed cassava flour as a substitute for wheat flour. There are three main arguments: the first one is that the nutritional composition of cassava flour is close to that of wheat flour, as shown in Table 2.

Table 2 Comparison of cassava flour and wheat flour composition [5].

\begin{tabular}{ccc}
\hline Component & Cassava flour & Wheat flour \\
\hline Water (\%) & 6.9 & 12 \\
Protein (\%) & 1.2 & $8-13$ \\
Ash (\%) & 0.4 & 1.3 \\
Starch (\%) & 87.3 & $60-68$ \\
Fiber (\%) & 3.4 & $2-2.5$ \\
Fat (\%) & 0.4 & $1.5-2$ \\
\hline
\end{tabular}

The second argument is the relatively easy plantation of cassava in Indonesia. Cassava plants can grow almost anywhere and during anytime of the year in Indonesia, even with low maintenance facilities. The third argument is the high productivity of cassava, where one hectare produces 40 tons on average [3]. Some plantations in Lampung produce an even higher number: 80 tons per hectare. This results in a low price for cassava flour.

Recently, cassava flour is being mass-produced, but its application in the food industry is not optimized yet. Generally, cassava flour is only being used as thickener or additive in the cake making process, not as a main ingredient.

There are three basic differences between cassava flour and wheat flour. First of all, cassava flour doesn't contain any gluten. Gluten is a protein compound in wheat flour that gives elasticity and extensibility in noodles. Secondly, Dziedzic and Kearsley [6] has found that, compared to other starches, cassava starch contains more amylopectin (87\%) than amylase. Amylopectin has a higher viscosity than amylase, resulting in stickiness and a higher viscosity in cassava starch. Last but not least, cassava also contains cyanogen compounds, which have to be removed prior to the cassava being used as a food ingredient. 
Other than flour, some basic ingredients of noodles mentioned by Sutomo [7] are: water, egg, salt, and alkali. The flour is the carbohydrate source. The dough consists of matrixes that are formed from flour and water. Salt is added to flavor the noodle, but it can also strengthen the structure, increase the elasticity and flexibility, in addition to bonding with water. Egg basically provides nutritive value to the noodles and the ability to not break easily. The egg-white can produce a thin and strong layer on the noodles surface. Egg-yolk consists of lecithin, which is widely known as a good emulsifier. Alkali water or q-water is used in noodle making; the purpose of the addition of alkali is to increase the elasticity and extensibility, and to soften the noodle's texture. Alkali can release $\mathrm{CO}_{2}$, causing the dough to expand. The usual alkali compounds that are used in noodles are: sodium carbonate, potassium carbonate, and phosphoric salt. The alkali dosage in noodles is $0.5-0.6 \%$ flour weight.

Ong states in [8] that there are some researches on the formulation of cassava flour-based wet noodles, but most researches have used wheat flour as their basic ingredient. Moreover, these researches did not conduct any market analysis for the final product. Therefore, this research proposes to formulate and develop a processing method for cassava flour-based wet noodles. The end product is designed to compete with a similar product made from wheat flour. Apart from reducing the consumption of imported wheat flour, this research could also give some fresh air to the Indonesian Food Industry.

\section{Materials and Methods}

The cassava flour goes through a fermentation process for acid removal and color bleaching, as described by Adams in [9]. The other ingredients, such as wheat flour, rice flour, sticky-rice flour, alkali water, salt, gluten, egg, baking powder, and vegetable oil, are standard materials in the market. A flour siever, mixer, sheeter and noodles cutter are the tools that were used in this research. All the kitchen utensils, such as bowl, plate and pan, were made from food grade materials.

The research started by making standard wet noodles with a $100 \%$ wheat flourrecipe (see Table $3 \mathrm{~A}$ ). The making process from the literature [10] consists of mixing, resting, sheeting, and cutting. The mixing process takes around 15-25 minutes. This time is needed to form the dough matrix and homogenize its ingredients. The purposes of resting are for water dispersion and gluten forming in the dough. Resting the dough for a long time will result in a softer noodle dough than can be stretched. The usual resting time is 30-60 minutes. Sheeting is done with a mechanical tool, and the end thickness of the noodle is $1.2-2 \mathrm{~mm}$. In this process, soft and extensible gluten fiber is being formed. The right 
temperature for this process is $25^{\circ} \mathrm{C}$ or higher, in order to avoid the dough becoming rough and broken. The noodle is then cut to a length of $0.5-1 \mathrm{~m}$.

The standard wet noodle was compared to several variations of cassava flour noodle formulations. Using trial-and-error experimenting, the research consisted of two main variations in ingredients and methods. The ingredient variations consisted of a variation in base flour (cassava flour, wheat flour); a variation in added flour (wheat flour, rice flour, sticky rice flour); alkali water composition $(60,70,80 \mathrm{~mL})$; egg composition (1or 0.5 pieces); gluten composition $(3 \%, 4 \%$, $5 \%, 12 \%, 22 \%)$; and cooking oil composition $(10 \mathrm{~mL}, 50 \mathrm{~mL})$. The method variations consisted of: ingredient mixing order (all in one, or one by one) and cooking method (6 minutes of steaming, 6 minutes of steaming +2 minutes of boiling). The conducted research is shown in Table 3.

Several respondents tested samples from each variation to obtain the optimum product data for several properties. The properties considered were: taste, texture, chewiness, flavor, and appearance, graded on a scale of 1 to 5 , as shown in Table 4. The best product obtained from the experiments was then tested in Center for Post-Harvest Technology (Balai Besar Penelitian Pasca Panen) Bogor for its nutritional value and graded by 100 panelists to gain a general response from the market.

\section{$3 \quad$ Result and Discussion}

\subsection{Product Outcome}

The several variations in composition and preparation method that are described in Table 3 have been assessed and tested to grade the product outcome of the wet noodles made from cassava flour. As depicted in Figure 1, it can be concluded that the best composition for cassava flour-based noodles was B5.

Table 3 Variation of experimental methods.

\begin{tabular}{|c|c|c|}
\hline No & \multicolumn{2}{|c|}{ Description } \\
\hline \multicolumn{2}{|c|}{ A: Wheat Flour Noodle (Standard) } & B: Cassava Flour Noodle \\
\hline B.1 & \multicolumn{2}{|c|}{ Using cassava flour sieved by regular seiver } \\
\hline B. 2 & \multicolumn{2}{|c|}{ Using alkali water, sieved cassava flourand wheat flour } \\
\hline B. $3 \mathrm{a}$ & \multicolumn{2}{|l|}{ B. 2 with $22 \%$ of glutenin } \\
\hline B. $3 b$ & \multicolumn{2}{|l|}{ B. 2 with $12 \%$ of glutenin } \\
\hline B. $3 \mathrm{c}$ & \multicolumn{2}{|c|}{ B. 2 with $12 \%$ of glutenin and reduction of egg } \\
\hline B. $3 \mathrm{~d}$ & \multicolumn{2}{|c|}{ B. 2 with $5 \%$ of glutenin and addition of flour } \\
\hline B.4 & \multicolumn{2}{|c|}{ Using of $4 \%$ of glutenin and cooking oil } \\
\hline $\begin{array}{l}\text { B. } 5 \\
\text { B. } 6\end{array}$ & \multicolumn{2}{|c|}{$\begin{array}{l}\text { Using of } 3 \% \text { of glutenin, wheat flour, cooking oil, and mixer mixing } \\
\text { Substituting wheat flour with rice flour }\end{array}$} \\
\hline B.7 & \multicolumn{2}{|c|}{ Substituting wheat flour with sticky-rice flour } \\
\hline
\end{tabular}


Table 4 Assessment scale.

\begin{tabular}{cccccc}
\hline Scale & $\begin{array}{c}\text { Taste value } \\
\text { description }\end{array}$ & $\begin{array}{c}\text { Texture } \\
\text { description }\end{array}$ & $\begin{array}{c}\text { Chewiness } \\
\text { description }\end{array}$ & $\begin{array}{c}\text { Aroma } \\
\text { description }\end{array}$ & $\begin{array}{c}\text { Appearance } \\
\text { description }\end{array}$ \\
\hline 1 & Awful taste & Unformable & Very brittle & Awful smell & Bad \\
2 & Less tasty & $\begin{array}{c}\text { Very fragile } \\
\text { Relatively fragile }\end{array}$ & $\begin{array}{c}\text { Brittle } \\
\text { Less chewy } \\
\text { Slightly } \\
\text { chewy }\end{array}$ & $\begin{array}{c}\text { Less aroma } \\
\text { So-so }\end{array}$ & Pess \\
Proper & Tasty & Less fragile & Proper & Attractive \\
4 & $\begin{array}{c}\text { Absolutely } \\
\text { tasty }\end{array}$ & Elastic & Proper & Good smell & $\begin{array}{c}\text { Absolutely } \\
\text { attractive }\end{array}$ \\
\hline
\end{tabular}

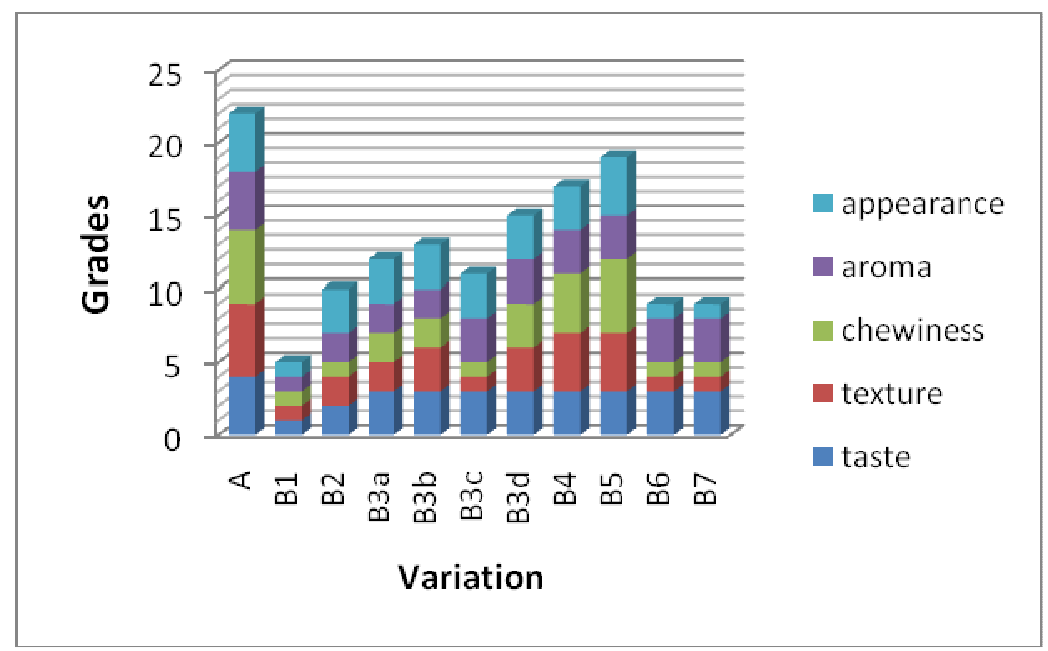

Figure 1 Grading results of prepared wet noodles.

The B5 variation of noodles was made from $250 \mathrm{gr}$ of cassava flour, $50 \mathrm{gr}$ of wheat flour, 1egg, $80 \mathrm{ml}$ of alkali water, $80 \mathrm{ml}$ of water, $15 \mathrm{gr}$ of gluten, 1 teaspoon of salt, and $50 \mathrm{ml}$ of vegetable oil, using the following method: mix the cassava flour, egg, salt, gluten and half of the alkali water with a mixer; pour in additional wheat flour, the other half of the alkali water and half of the water into the mixer; put additional oil and water into the mixture and mix them with the mixer; rest for 30 minutes; sheeting; cutting; steam for 6 minutes; and boil for 2 minutes.

The above composition and method are considered to be the best according to the five properties described below.

\subsubsection{Taste}

The taste of the noodles is affected by the particle size and the quality of the flour. Flour is the main component of the noodles, about $54 \% \mathrm{w} / \mathrm{w}$ of the dough. 
The cassava flour has been through a fermentation process that eliminates the real taste of cassava, so its application in noodle making should be similar to that of wheat flour. The particle size of the cassava flour, however, is still relatively big and hence gives the noodle a sandy feeling in the mouth. To reduce this, the cassava flour must be sieved in a 120 mesh or more.

Taste assessment has been done in the form of a questionnaire given to 10 panelists. Their opinions about the products' taste are presented in Figure 2.

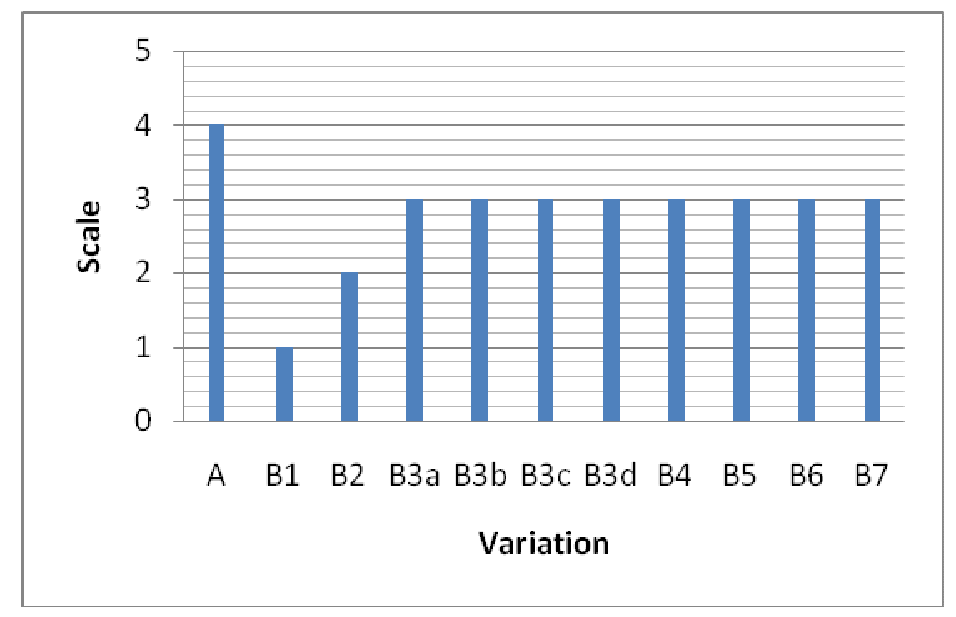

Figure 2 Taste Assesment Results.

The figure shows that the variations $\mathrm{B} 3 \mathrm{a}-\mathrm{B} 7$ received identical grades. Therefore, it can be concluded that addition of some materials does not produce a significant difference in taste.

\subsubsection{Texture}

The most affecting components for the noodle's texture are egg, vegetable oil, gluten and alkali water. Egg white produces a thin but strong layer on the noodle's surface, which makes it not break easily. Egg yolk contains lecithin, which is a good emulsifier. Lecithin is a surfactant that consists of fosfodic acid, choline, fatty acid, glycerol, glycolipid, trigliseride, and phospholipid. Lecithin can reduce the surface tension of the water to emulsified fat. Lecithin also reduces the surface tension between these two liquid components by absorption at the meeting point.

Vegetable oil can soften the dough's texture, so the end product noodle will not break easily. Oil and water are emulsified by egg yolk to arrange a stable composition. 
The texture assessment results are presented in Figure 3. In variations B6 and B7, the cassava flour was mixed with rice flour and sticky rice flour, and these variations proved to affect the noodle's texture significantly. As mentioned above, in flours other than wheat flour, there is no gluten, which is required to improve the elasticity of the noodle.

Alkali water is a solution mixture of sodium carbonate $\left(\mathrm{Na}_{2} \mathrm{CO}_{3}\right)$ and potassium carbonate $\left(\mathrm{K}_{2} \mathrm{CO}_{3}\right)$. This solution can increase elasticity, extendibility, soften the noodle's texture and expand the dough by releasing $\mathrm{CO}_{2}$. Sodium carbonate and potassium carbonate are leavening agents, or substances used in dough to cause foaming, which will soften and extend the dough.

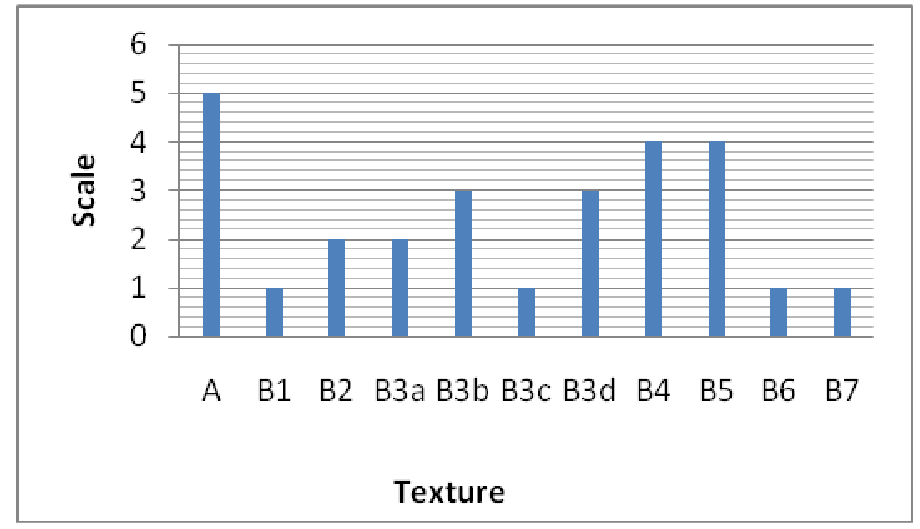

Figure 3 Texture Assessment Results.

These components react at a specific water content, heat and acidity, or environment to produce $\mathrm{CO}_{2}$ gas that will be trapped as bubbles in the dough. During the mixing or dough making process, the cassava starch and water will produce a matrix that is supported by gluten and then gelatinized. The $\mathrm{CO}_{2}$ will leave some holes in the dough, as Yanaka [11] and Potter [12] havefound. Water addition is proven to be very effective in improving noodle texture.

In variation B1, the regularly sieved cassava flour was proved to produce dough with a very bad texture that cannot even be formed into a noodle. When the size of the flour particles is too big, the dispersion of water and ingredients will be low.

The mixing step was also proven to affect the noodle texture. In variation B5, there were several steps and turns for the ingredients to be mixed. When all of the ingredients are fed into the mixer at the same time, part of the dough will be suspended and the other half will not form any dough. At the next trial, the flour was added gradually, and after 5 minutes of mixing the cassava flour and water, 
wheat the flour was fed to the mixer. A significant difference in the result was shown - the dough formed easily. Then at the following trial, the addition of the water and the alkali water were also done gradually. The outcome was dough with a good texture that can be formed into noodle sheets.

Wheat flour contains more protein than cassava flour, which enables it to emulsify easier. The water should also be added gradually to achieve a better distribution and hydration. However, further research is necessary to study each component's role.

\subsubsection{Chewiness}

The chewiness of the noodle is basically affected by the amylose to amylopectin ratio in the cassava flour. Dziedzic and Kearsley [6] have found that cassava flour contains $87 \%$ amylopectin. Amylopectin has a higher viscosity than amylose, and therefore, dough made with this flour will become sticky. Amylose gives the dough a firm and hard characteristic, while amylopectin gives it a soft characteristic. This difference is based on the molecular structure of these two components (Figure 4).

Noodle chewiness is also very dependent of gluten. Gluten gives the dough its viscoelasticity and makes the end product chewier. Gluten is a kind of protein, which consists of glutenin and gliadin. These proteins affect the strength of the noodle dough. Glutenin is a component that can increase the density and strength of the dough, because it increases the stability by a three-dimensional network that forms upon the development of the sulfur cross-linkage between the proteins in the dough making process. Gliadin is a glycoprotein component that is needed to improve and strengthen the dough. In the water, starch molecules will form a matrix with gluten.

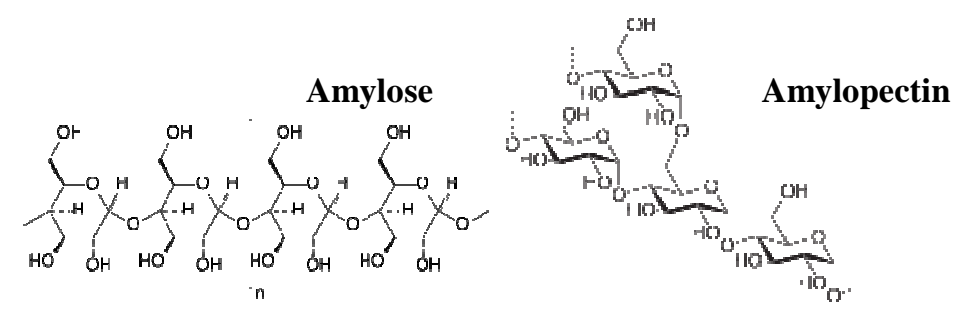

Figure 4 Amylose and amylopectin molecular structure.

Bietz and Carriere [13] confirm that gliadin's structure in suspension changes over a small concentration range, and gliadin is important in adjusting and controlling gluten's viscoelastic behavior, and not only as a diluent of gluten's functional properties. 
Table 5 The effect of gluten content on chewiness.

\begin{tabular}{cc}
\hline Gluten Composition (\%) & Chewiness Value \\
\hline $\mathbf{0}$ & 1 \\
$\mathbf{3}$ & 5 \\
$\mathbf{4}$ & 4 \\
$\mathbf{5}$ & 3 \\
$\mathbf{1 2}$ & 2 \\
$\mathbf{2 2}$ & 2 \\
\hline
\end{tabular}

According to the data in Table 5, we may conclude that a gluten content of $3 \%$ dough weight produces the best chewiness.

\subsubsection{Aroma}

Here, the main obstacle was an aroma that appeared upon mixing the cassava flour and the alkali water. The cassava flour still contained a number of acid components that reacted with the alkali water. The fermentation process in the making of cassava flour uses lactate acid bacteria to remove the cyanide components, thus acid is produced and contained in the cassava flour. However, the aroma from this process can be removed by boiling.

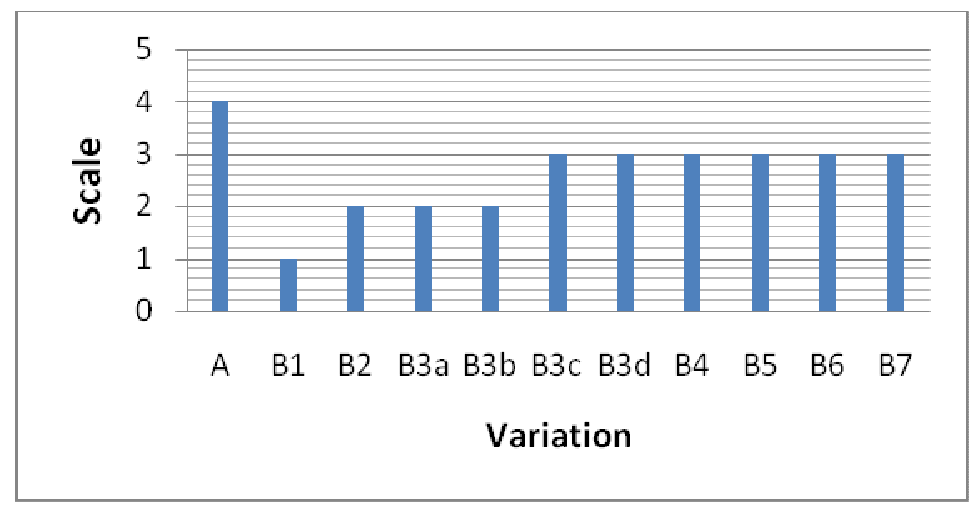

Figure 5 Aroma assessment results.

The aroma assessment results are presented in Figure 5. The egg contained in the noodle also affects the aroma. Egg contributes to the fishy smell in the noodle, but egg can't be eliminated from the ingredients because of its function as the noodle's texturizer. The optimum egg content is $10 \%$ of the flour weight.

\subsubsection{Appearance}

The appearance of the noodles was basically graded on the basis of color and shape. Alkaline salt diluted in the alkali water contributes to the yellow color of the noodle, which comes from pigments in the flour. 


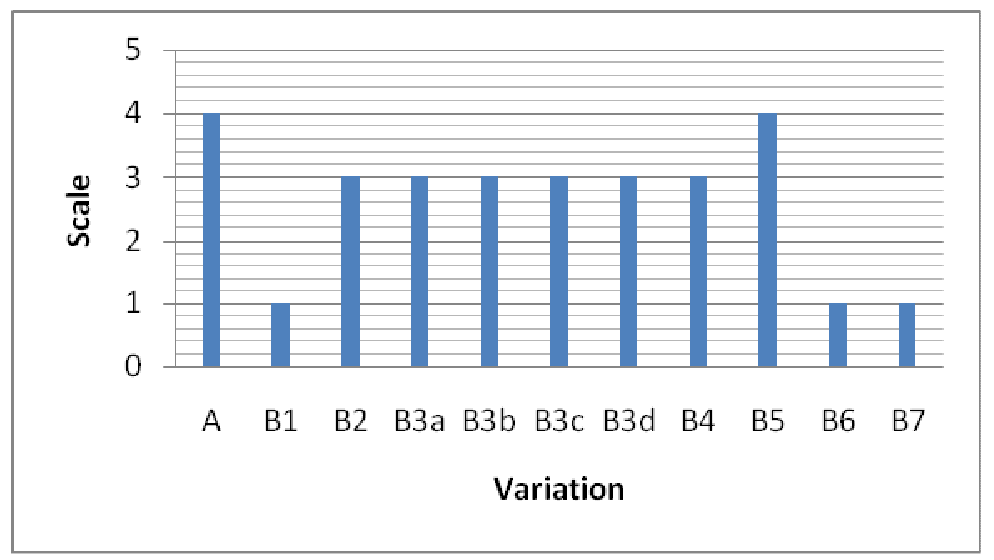

Figure 6 Appearance assessment results.

The appearance assessment results are presented in Figure 6. From all the variations, B5 had the best appearance, due to its good color and texture, which have some similarities with those of the wheat flour-based noodle (A).

Noodle B5 was boiled and steamed to produce the end product noodle. Steaming was done for 6 minutes at $96{ }^{\circ} \mathrm{C}$, and the noodle darkened and became firm. Before serving, the noodle was boiled for 2 minutes and the dark color that appeared earlier vanished. The boiling process was able to reduce the pigment that showed up during steaming, therefore the color of the noodle was lighter and more tempting.

\subsection{Market Response}

The cassava noodle variation with the best composition and processing method (B5) was then tested to the market. Samples were made in a number of batches, but consistent in quality. The noodles were then cooked and seasoned with standard additives that do not affect the original taste of the noodle. The added ingredients were onion oil, sesame oil, salty soy sauce, and pepper powder.

Wet noodle samples were distributed with a questionnaire to 100 panelists from a wide range of ages. All of the panelists were citizens of Bandung City. The composition of the age range is representative of the composition of the Bandung population (Figure 7). 


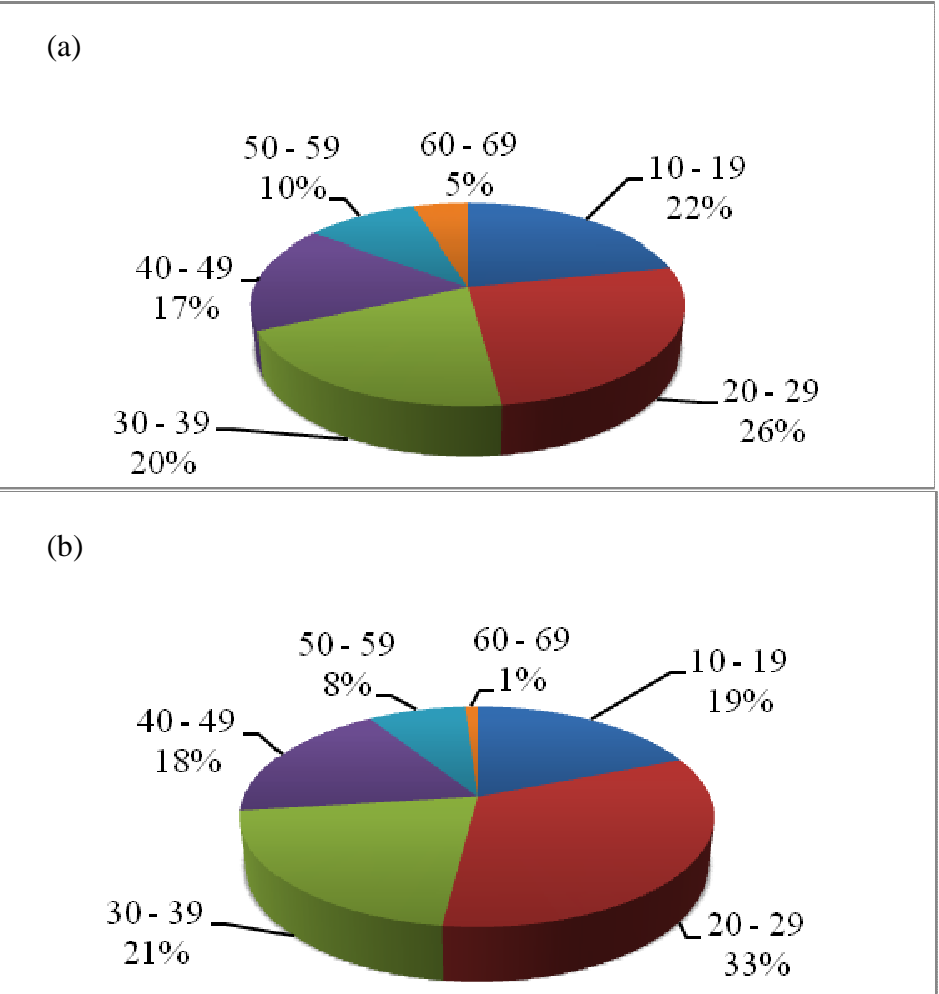

Figure 7 Comparison of the panelists based on years of age: (a) Bandung population, (b) respondents' population.

The panelists responded that the cassava noodle being tested fulfilled their criteria for noodles. Their responses are shown in Figure 8.

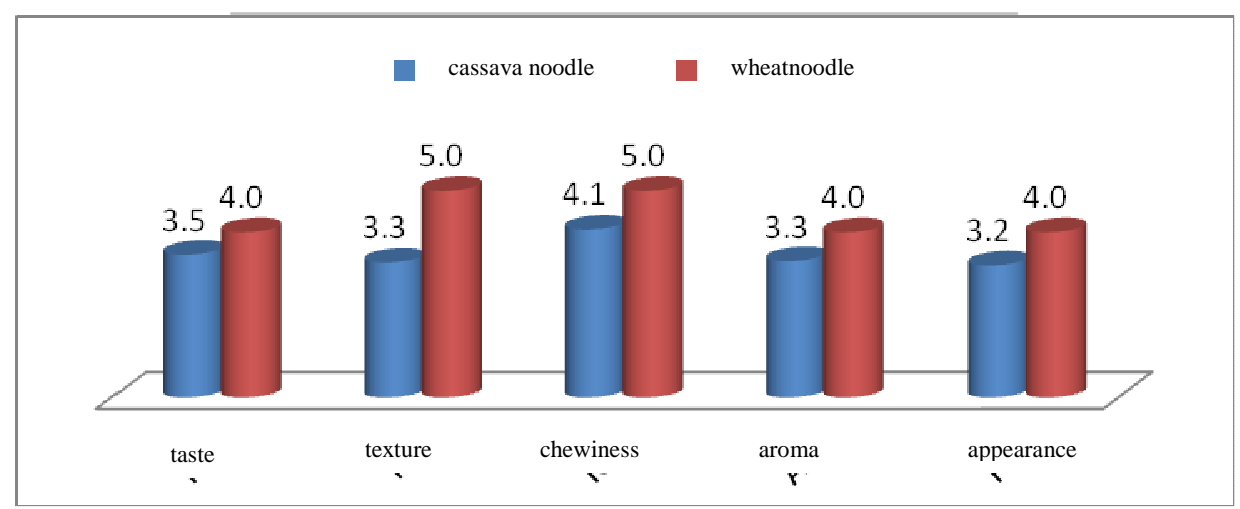

Figure 8 Panelists' responses of prepared cassava and wheat noodles 
Generally, the mean value for cassava noodles was 17.3. Compared to wheat noodles, with a value of 22 , the characteristics of the cassava noodles had a similarity of around $80 \%$.

Figure 9 shows that texture had the biggest gap in the grading results compared to wheat noodles. The cassava noodles were easier to break than standard wheat noodles, which are very elastic. In the categories taste and aroma, most panelists admitted there was no significant difference between the two types of noodles.

The appearance of the cassava noodle, which was a little bit too dark, can be improved by improving the color of the cassava flour. The use of tartrazine color additives is another option for improving the color of the noodle.

Figure 9 shows the general response seen from the panelists' age point of view. The graphic shows that the highest scores came from age 10 to 19; immaturity caused them to be less critical in their product evaluation. Age group 30-59 also gave high scores, because the nutritional value and price of the noodles seem to be more important for this group. Age group 20-29 gave the lowest scores; this group mostly consisted of students from the Food Technology Program at the Chemical Engineering Department of ITB, who are assumed to be pretty critical and have high standards of food evaluation.

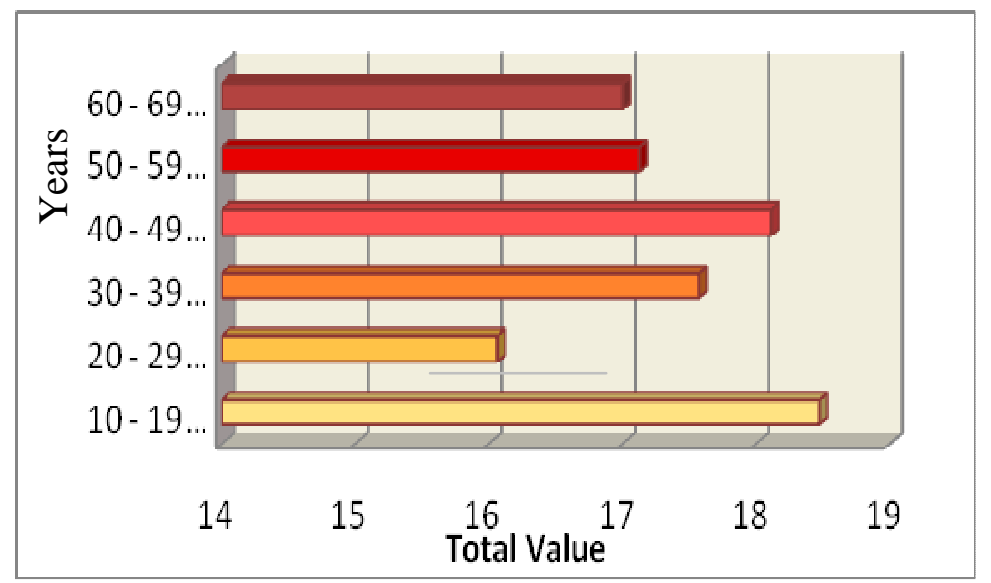

Figure 9 Market response from panelists'age point of view.

\subsection{Nutrition Compatibility}

From the panelists' response in this research, we obtained the best composition, that is variation B5. Subsequently, this variation was analyzed for its nutritional values. The analysis results are presented in Table 6. 
Table 6 Cassava flour noodle, nutritional values.

\begin{tabular}{cc|c}
\hline Nutrition & \multicolumn{2}{c}{ Value } \\
\hline Fat & 0.27 & \\
Protein & 5.01 & $\%$ \\
Water & 41.92 & \\
Carbohydrate & 52.68 & \\
\hline Sodium & 708.29 & $\mathrm{mg} / 100 \mathrm{~g}$ \\
\hline
\end{tabular}

In general, this wet noodle has a good nutritional value and is safe to be consumed. The fat content of the noodle is relatively small ( $0.27 \%)$ compared to other wet noodles (1-2.5\%). This could contribute to a high market value, because less fat is something that the market demanded nowadays. The sodium content $(0.7 \%)$ is $29.5 \%$ of the standard sodium daily intake $(2400 \mathrm{mg}$ ) [14]. Moreover, the protein content of this product $(5.01 \%)$ is also beyond the range of common wet noodles (4.6-6\%). The same is the case for carbohydrate and water content as well.

\subsection{Economical Analysis}

A simple economical analysis was carried out in this research, based on gross profit margin (GPM). GPM is the margin between the product's selling price and the price of the raw materials. This parameter determines the feasibility of cassava noodle fabrication. The costs of producing this wet noodle are summarized in Table 7.

Table 7 Raw material costs of cassava flour-based wet noodle.

\begin{tabular}{ccccc}
\hline Material & Amount & \multicolumn{2}{c}{ Price per unit $(\mathbf{R p )}$} & Total price $(\mathbf{R p )}$ \\
\hline cassava flour & $500 \mathrm{gr}$ & 4,000 & per kg & 2,000 \\
wheat flour & $100 \mathrm{gr}$ & 8,000 & per kg & 800 \\
egg & 2 pieces & 12,000 & per kg & 1,200 \\
alkali water & $80 \mathrm{~mL}$ & 7,500 & per $620 \mathrm{~mL}$ & 968 \\
salt & 1 teaspoon & 4,000 & per kg & 40 \\
glutenin & $30 \mathrm{gr}$ & 30,000 & per kg & 900 \\
cooking oil & $100 \mathrm{~mL}$ & 9,000 & per L & 900 \\
\hline \multicolumn{5}{c}{ Total material cost/kg product } \\
\multicolumn{5}{c}{}
\end{tabular}

These amounts of raw materials produce an amount of $1 \mathrm{~kg}$ wet noodles. On that basis, the price for cassava noodle fabrication is assumed to be $\mathrm{Rp}$ $8,500 / \mathrm{kg}$. This number can be considered as relatively cheap compared to wheat flour-based wet noodles, which are sold at Rp 10,000-12,000/kg. Based on the 
selling price and raw material costs, we obtain a GPM of Rp 1,692. Therefore, this product is economically feasible to be produced.

\section{Conclusion}

The research has resulted in the selection of a specific composition of wet noodles that fulfilled the desired physical and nutritional specifications. The selected noodle consisted of cassava flour and wheat flour with ratio of 5:1; egg, gluten, salt, alkali water, water, and vegetable oil. This noodle was processed in several stages using a one by one mixing method. The market response to these noodles showed that its characteristics have $80 \%$ similarity with those of wheat flour noodles.

\section{Acknowledgements}

A special thanks goes to PT. DKSH, which has provided us with the cassava flour used as raw material for this research, and to Dr. Yazid Bindar, who gave helpful suggestions and facilities throughout this research.

\section{References}

[1] Indonesian Wheat Flour Importations, www.trademap.org, (20 February 2012)

[2] Food Crops Statistics, Badan Pusat Statistik (BPS),www.bps.go.id, (15 April 2011)

[3] Indochemical, Laporan No. 4031 June 2005, www.cic.co.id, (15 April 2011)

[4] Abidin, A.Z., Devi, C. \& Adeline, Mie Basah Berbahan Dasar Tepung Singkong: Pengembangan Formulasi, Proses Produksi dan Karakterisasi Produk, Seminar Nasional Teknik Kimia Indonesia, 2009.

[5] MOCAF Product Specification, PT. Rajawali Nusindo, www.gongchang. com/Modified_Cassava_Flour_MOCAF-dp1709033/ (11 August 2010)

[6] Dziedzic, S.Z. \& M.W. Kearsley, The Technology of Starch Production. Handbook of Starch Hydrolysis Products and Their Derivatives, Blackie Academic and Professional, London, pp.1-25, 1995.

[7] Sutomo, B., Sejarah dan Aneka Jenis Mie, www.budiboga.blogspot.com (5 Mei 2006).

[8] Ong, C., Effects of Gluten Composition and Molecular Weight Distribution on the Noodle Making Potential of Hard White Wheats, Bachelor Thesis, Bioresource Research Biotechnology, Oregon State University, Oregon, 2003.

[9] Adams, S., Noodles-Gluten Free, www.celiac.com (26 August 1996). 
[10] Ebookpangan, Teknologi Mie Instan, www.ebookpangan.com. (11 August 2010)

[11] Yanaka, M., Effect of High Molecular Glutenin Allele, Glu-Dld, on Noodle Quality of Common Wheat, Breeding Science, 57, pp.243-248, 2007.

[12] Potter, N.N., Food Science, $5^{\text {th }}$ ed., Chapman \& Hall, USA, 1995.

[13] Bietz, J.A. \& Carriere, C.J., The Viscoelastic Properties of Wheat Gliadin and Glutenin Suspensions, Food Chemistry, 101(2007), pp.1025-1030, 2006.

[14] Recommended Daily Intake, Canadian Food Inspection Agency.www.inspection.gc.ca. (24 September 2012) 